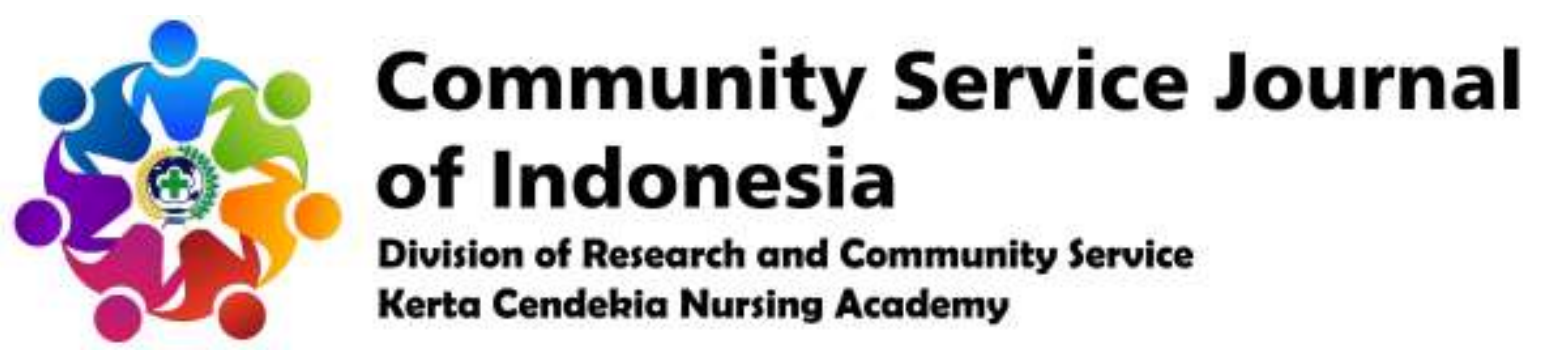

https://ejournal-kertacendekia.id/index.php/csji/index

Community Service Journal of Indonesia 3 (1) (2021): 15-20

Doi: https://doi.org/10.36720/csji.v3i1.288

\title{
HEALTH LIFESTYLE "SEHATI" AMONG ELDERLY IN JAMBANGAN NURSING HOME SURABAYA
}

\author{
Lono Wijayanti ${ }^{1 *}$, Yurike Septianingrum ${ }^{1}$ \\ ${ }^{1}$ Faculty of Nursing and Midwifery, Universitas Nahdlatul Ulama Surabaya \\ * Correspondence \\ Lono Wijayanti \\ Faculty of Nursing and Midwifery, Universitas Nahdlatul Ulama Surabaya \\ SMEA Road 57, Surabaya City, East Java Province, Indonesia \\ Email: lono@unusa.ac.id
}

\begin{abstract}
Getting older means increasing health problems faced. The degenerative process in the elderly causes a decrease in physical, psychological and social conditions. Hypertension is a disease that has a very close relationship with the elderly. The purpose of this community service activity is to increase knowledge about the importance of a healthy lifestyle called SEHATI (Sehat Tanpa Hipertensi) among the elderly at the Jambangan nursing home Surabaya. This community service was held on July 8, 2020 at the Jambangan Nursing Home in Surabaya, which was attended by 56 elderly people. The method used is through counseling and blood pressure checks. Counseling uses lecture and question and answer methods. Most of the elderly are female (73.2\%), most (73.2\%) are aged 6074 years, almost half $(42.9 \%)$ have first-degree hypertension (140-159/90-99mmHg). Before counseling as many as $14 \%$ of the elderly knew about hypertension and how to prevent it, and after this activity as many as $88 \%$ of the elderly experienced an increase in knowledge. Providing education can improve a healthy lifestyle, so that people are more aware of the importance of a healthy lifestyle so that blood pressure can be controlled properly.
\end{abstract}

Keywords: Hypertension, healthy lifestyle, SEHATI (Sehat tanpa Hipertensi), elderly.

(C) 2021 The Authors. Community Service Journal of Indonesia Published by Institute for Research and Community Service, Health Polytechnic of Kerta Cendekia, Sidoarjo

This is an Open Access Article distributed under the terms of the Creative Commons Attribution 4.0 International License which permits unrestricted non-commercial use, distribution, and reproduction in any medium, provided the original work is properly cited.

\section{E-ISSN \\ 2684-7884 \\ P-ISSN \\ 2774-4027}

\section{INTRODUCTION}

Getting older is accompanied by health problems faced. The degenerative process in the elderly causes a decrease in physical, psychological and social conditions. Hypertension is a disease that has a very 
close relationship with the elderly. This occurs due to physiological changes that occur such as decreased immune response, thickened and stiff heart valves, decreased contractility of the heart, reduced elasticity of blood vessels, and reduced effectiveness of peripheral blood vessels for oxygenation. These changes cause an increase in vascular resistance so that the elderly tend to be more susceptible to hypertension (Setiawan et al, 2013).

Hypertension is a disease of the blood vessels that results in the supply of oxygen and nutrients carried by the blood being blocked to the body's tissues (Wahyuningsih, 2013). Hypertension or better known as high blood pressure is a condition in which a person experiences an increase in blood pressure above normal. Hypertension is a major risk factor for heart disease and stroke. Hypertension is also referred to as "the silent killer" because many people cannot see signs or symptoms from the outside. The development of hypertension proceeds slowly, but is potentially very dangerous (Syamsiah, 2017).

The World Health Organization (WHO) in 2014 stated that the Indonesian population experienced hypertension by 23.3\%. Data from the World Health Organization (WHO) in 2012 shows that around the world around 972 million people or $26.4 \%$ of the earth's inhabitants suffer from hypertension with a ratio of $26.6 \%$ men and $26.1 \%$ women. This figure is likely to increase to $29.2 \%$ by 2030 .

Based on data from Riskesdas (2018), the incidence of hypertension in East Java is $36.3 \%$. Integrated surveillance of hypertension at health centers in East Java showed that the number of visits with hypertension patients increased from 2014 with a total of 530,070 visitors to 536,199 visitors in 2015. Based on the profile of the Surabaya City Health Office, the incidence of hypertension in Surabaya from year to year is always in the top 10 lists. most diseases. According to Riskesdas 2018 data, the incidence of hypertension in Surabaya reached $31.5 \%$.

Several trigger factors that influence the occurrence of hypertension, namely factors that cannot be controlled, including heredity, age and gender. While the factors that can be controlled include obesity, excessive salt consumption, lack of exercise, smoking, alcohol consumption and stress (Syamsiah, 2017). In addition to the above factors, it is caused by increased cardiac output, sympathetic nerve activity and increased levels of angiotensin and aldosterone (Guyton \& Hall, 2014). As a result, if hypertension is not treated properly, complications will occur, such as heart failure, kidney failure, coronary heart disease, damaged blood vessels and eye abnormalities (Puspita \& Immelati, 2013).

To prevent hypertension, a healthy lifestyle is important to do. By living a healthy lifestyle, blood pressure can be well controlled and in general will reduce the risk of cardiovascular problems. A healthy lifestyle is a person's efforts to keep his body healthy. Most of us think that a healthy lifestyle is a lifestyle that is difficult to live. A healthy lifestyle includes physical activity, balanced BMI (body mass index) values, regulating diet by consuming lowsalt and low-fat foods and increasing consumption of vegetables and fruit, avoiding alcoholic beverages and stopping smoking habits (Kemenkes RI, 2009).

Providing education is the main thing in improving a healthy lifestyle, so that people are more aware of the importance of maintaining a healthy lifestyle. Several studies have stated that respondents who 
regulate their diet, regulate salt consumption and do not smoke have a better level of lifestyle and adherence to therapy (Venkatachalman et al, 2015).

However, there is still a lack of public awareness in maintaining a lifestyle, this can be caused by several things, one of which is the lack of public knowledge about the importance of maintaining a lifestyle. Knowledge is the result of a learning process involving the senses of sight, hearing, smell and taste. Knowledge will provide reinforcement for individuals in every decision making and in behavior (Dermawan et al, 2008).

\section{OBJECTIVES}

\section{General Purpose}

The purpose of this community service activity is to increase knowledge about the importance of a healthy lifestyle called SEHATI (Sehat Tanpa Hipertensi) among the elderly at the Jambangan Nursing Home Surabaya.

\section{Special Purpose}

After this health education activity is carried out, it is hoped that the elderly in Jambangan Nursing Home Surabaya will be able to:

1. Know about hypertension.

2. Know about the causes of hypertension.

3. Know about the signs and symptoms of hypertension.

4. Learn about hypertension prevention.

\section{PLAN OF ACTION}

\section{Strategy Plan}

The implementation method in this community service program is through counseling and checking blood pressure for the elderly in Jambangan nursing home, which includes 3 (three) stages, namely: 1) Implementation strategy meeting led by the chief executive to discuss the strategy and planning of community service programs being implemented, 2) Site survey, 3) Preparation of facilities and infrastructure (LCD, stethoscope, sphygmomanometer, and laptop).

\section{Implementation}

The implementation stage is the main stage of the community service program. Respondents of activities at the implementation stage were the elderly in the nursing home nursing home in Surabaya. For assistance to the community, we divided into four activity sessions. Distribution of implementation as follows:

1) Pre test

Pretest is an activity to test the respondent's level of knowledge about hypertension. This activity is carried out before the presentation by the presenter. The level of knowledge was measured using a questionnaire sheet.

2) Health education abaout healthy lifestyle SEHATI (Sehat Tanpa Hipertensi) as an effort to prevent hypertension. Counseling will be delivered by the chairman and members of implementing community service activities using lectures and equipped with blood pressure checks.

3) Discussion (question and answer)

The discussion process about the material includes questions and answers between the presenter and the counseling participants.

4) Post test

Post test is an activity to test the respondent's level of knowledge about the material that has been delivered by the presenter. This activity aims to determine the increase in respondents' knowledge before and after listening to the presentation or counseling delivered 
by the presenter.

\section{Setting}

This community service was held on July 8, 2020 at the Jambangan Nursing Home in Surabaya

\section{Target}

Target in this activity are all the elderly in the Jambangan nursing home, Surabaya which was attended by 56 elderly.

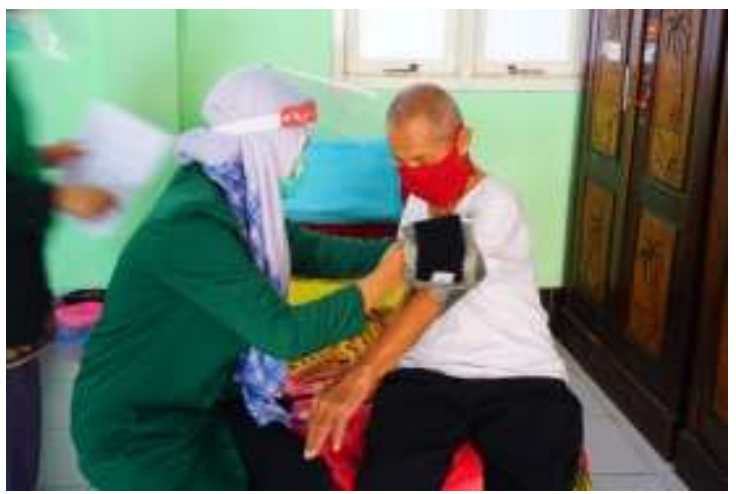

\section{RESULTS AND DISCUSSION}

The results of community service are as follows:

Table 1. Distribution of Respondents by Gender.

\begin{tabular}{clcc}
\hline No & Gender & Freq $(\mathrm{n}$ & $\begin{array}{c}\text { Percentage } \\
(\%)\end{array}$ \\
\hline 1 & Male & 15 & $26,8 \%$ \\
2 & Female & 41 & $73,2 \%$ \\
\hline \multicolumn{2}{c}{ Total } & 56 & $100 \%$ \\
\hline
\end{tabular}

Based on table 1 shows that of the 56 respondents most $(73.2 \%)$ are women.
Table 2. Distribution of Respondents by Age.

\begin{tabular}{cccc}
\hline No & Age & $\begin{array}{c}\text { Freq } \\
(\mathrm{n})\end{array}$ & $\begin{array}{c}\text { Precentage } \\
(\%)\end{array}$ \\
\hline 1 & $60-74$ & 41 & $73,2 \%$ \\
& y.o & & \\
2 & $75-90$ & 15 & $26,8 \%$ \\
& y.o & & \\
\hline \multicolumn{2}{c}{ Total } & 56 & $100 \%$ \\
\hline
\end{tabular}

Based on table 2 shows that of the 56 respondents most $(73.2 \%)$ of respondents aged 60-74 years.

Table 3. Distribution of Respondents by Blood Pressure.

\begin{tabular}{|c|c|c|c|}
\hline No. & Blood Pressure & $\begin{array}{c}\text { Frequency } \\
\text { (n) }\end{array}$ & $\begin{array}{c}\text { Percentage } \\
(\%)\end{array}$ \\
\hline 1 & $\begin{array}{l}\text { Normal (120- } \\
129 / 80- \\
84 \mathrm{mmHg})\end{array}$ & 15 & $26,8 \%$ \\
\hline 2 & $\begin{array}{l}\text { Normal-High } \\
(130-139 / 85-89 \\
\mathrm{mmHg})\end{array}$ & 12 & $21,4 \%$ \\
\hline 3 & $\begin{array}{l}\text { First Level } \\
\text { Hypertension } \\
(140-159 / 90-99 \\
\mathrm{mmHg})\end{array}$ & 24 & $42,9 \%$ \\
\hline 4 & $\begin{array}{l}\text { Second Level } \\
\text { Hypertension } \\
(160-179 / 100- \\
109 \mathrm{mmHg})\end{array}$ & 5 & $8,9 \%$ \\
\hline & Total & 56 & $100 \%$ \\
\hline
\end{tabular}

Based on table 3 shows that of the 56 respondents, almost half (42.9\%) had first level hypertension (140-159/9099mmHg). 
Table 4. Knowledge About Hipertension.

\begin{tabular}{cccccccc}
\hline & \multicolumn{3}{c}{ Pre-Test } & \multicolumn{3}{c}{ Post Test } \\
\hline Know & \multicolumn{2}{c}{$\begin{array}{c}\text { Do not } \\
\text { know }\end{array}$} & Know & \multicolumn{2}{c}{$\begin{array}{c}\text { Do not } \\
\text { know }\end{array}$} \\
\hline N & $\%$ & N & $\%$ & N & $\%$ & N & $\%$ \\
\hline 8 & 14 & 48 & 86 & 49 & $88 \%$ & 7 & 12 \\
\hline
\end{tabular}

Based on table 4 pre-test and post-test counseling attended by 56 respondents, it can be stated that the results of the pre-test about respondents who know about hypertension disease are 8 respondents $(14 \%)$. Meanwhile, based on the results of the post test of respondents who know about hypertension as many as 49 respondents $(88 \%)$.

Judging from the results of the pre test, most of the elderly who live in Jambangan nursing home do not know about hypertension. However, after counseling, the results of the post-test most of the elderly knew about hypertension. It can be concluded that there is an increase in the knowledge of the elderly because the post test value is higher than the pre test value.

Knowledge of each individual is different. Knowledge is the result of knowing and this happens after people sense a certain object. Knowledge and cognitive are very important domains for the formation of one's actions (Notoatmodjo, 2007). Knowledge of hypertension sufferers can be increased by providing health education. However, this health education is influenced by several factors originating from the respondents. Based on the distribution table, we can see that some respondents have different characteristics. This of course affects the process of receiving the information provided.

Reception of information in the provision of knowledge is also influenced by the age and experience of the respondent. The older age shows the level of maturity and strength of a person will be more mature in thinking. However, according to DW (2000) increasing age results in a decrease in cognitive function. This is also supported by research conducted by Miller (2009) which says that increasing age will lengthen the time it takes to remember an information that has been obtained.

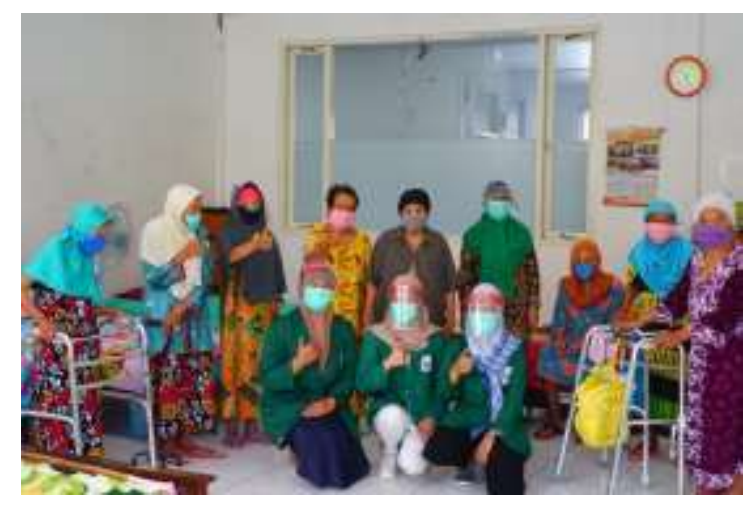

\section{CONCLUSION}

The understanding of the elderly about the importance of a healthy lifestyle in preventing hypertension increased after health education and counseling were carried out. The level of knowledge of respondents regarding knowledge, about hypertension, which was followed by 56 respondents, it can be stated that the results of the pre test 8 respondents (14\%) knew about hypertension. Meanwhile, based on the post test result, 49 respondents (88\%) knew about hypertention. Based on the results of blood pressure measurements, almost half $(42,9 \%)$ had first level hypertention.

\section{REFERENCES}

Adib, M. (2009). Cara Mudah Memahami dan Menghindari Hipertensi, Jantung dan Stroke. Edisi I. Yogyakarta: CV. Dianloka. 
Endang, Triyanto (2014). Pelayanan

Keperawatan Bagi Penderita

Hipertensi Secara Terpadu.

Yogyakarta: Graha Ilmu.

Gunawan. (2016). Hipertensi (Tekanan

Darah Tinggi). Yogyakarta : Kanisius

Kementrian Kesehatan RI. (2014).

Pedoman Gizi Seimbang, Jakarta

Mujadihullah, Khalid. (2012).

Keperawatan Gerontik. Jogjakarta:

Pustaka Pelajar.

Novitasari. (2017). Mengenal, Mencegah, Mengatasi Hipertensi. Semaranag : Pustaka Widyamara

Purwanto. (2017). Keperawatan Lanjut Usia. Yogyakarta : Graha Ilmu

Pusat Data dan Informasi Kementerian RI. (2015). Infodatin Info Data dan Informasi Kementrian Kesehatan RI Hipertensi. Jakarta: Pusat Data dan Informasi Kementerian RI.

Venkatachalam, J., Abrahm, S.B., Singh, Z., dan Satya., S. (2015). Determinants of Patient's Adherence to Hypertension Medication in a Rural Population of Kancheepuram District in Tamil Nadu, South India, Indian J Community Med. 